Ardea107_721795_Pot

Pot et al: : HABITAT SWITCHING IN BARNACLE GEESE

\title{
Wintering geese trade-off energy gain and costs when switching from agricultural to natural habitats
}

\author{
Morrison Thomas Pot ${ }^{1,2, *}$, Susan de Koning1, Coen Westerduin ${ }^{3,4}$, Willem Frederik de \\ Boer $^{1}$, Mitra Shariati ${ }^{5}$ \& Thomas Koert Lameris ${ }^{2,6,7}$
}

Pot M.T., de Koning S., Westerduin C., de Boer W.F., Shariati M. \& Lameris T.K. 2019. Wintering geese trade-off energy gain and costs when switching from agricultural to natural habitats. Ardea 107: \#\#\# \#\#\#. doi:10.5253/arde.v107i2.a6

Migratory birds need considerable energy reserves to fuel long-distance flights to their breeding grounds in spring. To attain sufficient energy deposits before departure, birds require high daily intake rates, which can be reached by utilizing high-quality food. During such periods of high energy demand, animals often track changes in the nutritious value of their food, for example by switching to a more profitable habitat or diet. Pre-migratory Barnacle Geese Branta leucopsis staging along the Wadden Sea coast are known to switch from pastures to salt marshes during spring. Previous studies have suggested that Barnacle Geese switch habitat to track changes in protein levels, which drop in pastures as spring progresses, and to avoid high levels of disturbance. Here we made use of detailed information on pre-migratory habitat use of individual Barnacle Geese tracked by GPS/accelerometer tags to assess which factors may drive a habitat switch. We analysed habitat use and time budgets of individual birds and combined this with data on food quality in two habitats to analyse differences in food intake. We found large individual variation in pre-migratory habitat use, both in the extent of salt marsh use, as well as in the timing of a switch from pastures to salt marshes. In salt marshes, geese spent more time grazing and made fewer flight movements, potentially as they experienced lower levels of disturbance compared to geese in pastures. By increasing grazing time and reducing flight movements, geese in salt marshes may compensate for reduced food quality. Our results show that Barnacle Geese trade-off high intake rates and high costs in pastures with low intake rates and low costs in salt marshes.

Key words: migratory bird, herbivore, habitat switch, Barnacle Goose, Branta leucopsis, intake rates

${ }^{1}$ Resource Ecology Group, Wageningen University, Droevendaalsesteeg 3a, 6708 PB, Wageningen, The Netherlands; ${ }^{2}$ Department of Animal Ecology, Netherlands Institute of Ecology (NIOO-KNAW), Droevendaalsesteeg 10, 6708 PB, Wageningen, The Netherlands; ${ }^{3}$ Plant Ecology and Nature 
Conservation Group, Wageningen University, Droevendaalsesteeg 3a, 6708 PB, Wageningen, The Netherlands; ${ }^{4}$ Present address: Department of Ecology and Genetics, University of Oulu, P.O. Box 3000, 90014, Oulu, Finland; ${ }^{5}$ Faculty of Geo-Information Science and Earth Observation (ITC), University of Twente, P.O. Box 217, 7500 AE, Enschede, The Netherlands; ${ }^{6}$ Theoretical and Computational Ecology, Institute for Biodiversity and Ecosystem Dynamics (IBED), University of Amsterdam, Amsterdam, the Netherlands; ${ }^{7}$ NIOZ Royal Netherlands Institute for Sea Research, and Utrecht University, PO Box 59, 1790 AB Den Burg, The Netherlands; *corresponding author (morrisonpot@gmail.com)

Migratory birds undertake annual long-distance flights between wintering areas and breeding grounds during which most rely on internal energy stores (Alerstam et al. 2003). Energetically costly migration flights are fuelled by energy in the form of fat and protein which are stored prior to migration and refuelled during migration at stopovers (Zwarts et al. 1990, Lindström 1991, Klaassen \& Biebach 1994, Jenni \& Jenni-Eiermann 1998, Warnock 2010). Larger birds, such as geese and swans, bring additional energy stores to their breeding grounds for reproduction (capital breeding; Drent \& Daan 1980) which allows for relatively early arrival and egg laying, thereby enabling their offspring to profit from a peak in food availability after hatching (Meijer \& Drent 1999, van der Graaf et al. 2006, Drent et al. 2007, Kölzsch et al. 2015). A strong relationship between the body condition of females at departure and the number of young produced in the subsequent breeding season has been found in Dark-bellied Brent Geese Branta b. bernicla (Ebbinge \& Spaans 1995) and Pink-footed Geese Anser brachyrhynchus (Klaassen et al. 2017), suggesting that geese rely on energy and nutrient reserves flown in from the wintering grounds for successful reproduction.

Pre-migratory accumulation of energy stores causes dramatic changes as some birds double in body mass within a couple of weeks (Zwarts et al. 1990, Lindström \& Piersma 1993, Piersma 1998). Because carrying extra mass is costly, energy deposition should occur fast and shortly before migration (Lindström 1991). Migrants therefore require high daily intake rates of high-quality food (Ebbinge et al. 1975, Drent \& Prins 1987, Prop \& Vulink 1992). Often, a switch in either habitat or diet allows for continuous utilization of high food abundances and/or high food quality (Mckay et al. 1994). Examples are found in several species of herbivorous waterfowl, which switch foraging habitats following changes in food quality (Madsen 1985, Prins \& Ydenberg 1985, Vickery et al. 1995, McWilliams \& Karasov 2001, Nolet et al. 2002). Because avian herbivores have a relatively simple digestive system, food plants with high digestibility and low fibre content are selected (Sedinger 1997, Prop \& Black 1998). Therefore, habitat switches in waterfowl are often driven by changes in protein content and digestibility of food plants (Ydenberg \& Prins 1981, Drent \& Prins 1987, Fryxell \& Sinclair 1988, Fryxell 1991). For example, Barnacle Geese Branta leucopsis graze in pastures during winter but switch to salt marshes prior to spring migration (Ydenberg \& Prins 1981, Prins \& Ydenberg 1985). Protein levels in pastures drop as spring progresses and geese switch to salt marshes as soon as protein levels there match those found in pastures, suggesting that salt marshes are 
the preferred habitat. In addition, lower levels of disturbance are believed to allow for improved digestion of carbohydrates (Prins \& Ydenberg 1985).

Geese increasingly use nutrient-rich agricultural fields during the non-breeding period (van Eerden et al. 2005), and have become more dependent on agricultural crops as a food source due to increasing populations, loss of natural habitat and advancing crop phenology, but mainly because agricultural crops are energetically superior to natural grasslands (Bédard \& Gauthier 1988, Abraham et al. 2005, Gauthier et al. 2005, Fox et al. 2010, 2016, Eichhorn et al. 2012). Agricultural crops are easily digested and provide geese with high energy intake (Bédard \& Gauthier 1988, Prop \& Black 1998). In the case of Barnacle Geese, switching from pastures to salt marshes during spring staging, as described by Prins \& Ydenberg (1985), may no longer be optimal when pastures provide highquality food plants throughout the entire spring (van der Jeugd et al. 2001, Si et al. 2011). However, it has been suggested that agricultural crops may not provide geese with sufficient protein deposition, whereas natural grasslands would provide geese with necessary nutrients for reproduction (Prop \& Black 1998, Prop \& Spaans 2004). Yet, Eichhorn et al. (2012) found no differences in overall protein content and composition of amino acids among food plants in pastures and salt marshes, suggesting no impaired protein deposition in geese primarily using pastures. Although potential intake rates may be higher in pastures, the energetic costs may also be higher due to increased disturbance caused by human encounters (Owens 1977, Prins \& Ydenberg 1985, Riddington et al. 1996, Nolet et al. 2016).

Here we investigate which factors may drive a seasonal habitat switch from pastures to salt marshes prior to spring migration in Barnacle Geese wintering along the North Sea and Wadden Sea coast. We specifically ask if changes in food quality, forage intake rates and levels of disturbance can explain a habitat switch, and whether this affects subsequent reproductive success. Combining remotely acquired spatial and behavioural data with data on food quality, intake rates and reproductive success allows us to assess the importance of these drivers. We expect that habitat selection is based on maximizing energetic gains and minimizing costs, where geese should make a switch if they can thereby increase fat and/or protein deposition or decrease energy expenditure.

\section{METHODS}

\section{GPS-data}

In the summer of 2014, in the breeding colony of the Kolokolkova Bay, northern Russia $\left(68^{\circ} 40^{\prime} \mathrm{N}\right.$, $52^{\circ} 17^{\prime} \mathrm{E}$; van der Jeugd et al. 2003), 40 incubating female Barnacle Geese were captured on their nests using spring-traps. UvA-BiTS GPS/accelerometer tags (19 g; Bouten et al. 2013) were attached to these geese with Teflon backpack harnesses (Lameris et al. 2017, 2018a). GPS-data was remotely downloaded from 23 GPS/accelerometer tags in the summer of 2015 at the Kolokolkova Bay. The GPS/accelerometer tags stored GPS-locations every $30 \mathrm{~min}$ and recorded 10 tri-axial accelerometer measurements $(0.5 \mathrm{~s})$ at $20 \mathrm{~Hz}$ after every GPS-fix. In this study we make use of the GPS- and accelerometer-data collected during winter and spring staging, from 1 January up to departure in late May 2015, the period during which geese reside along the North Sea and Wadden Sea coast (Figure 
1). We assumed birds to have departed this region as soon as the longitude of their location was $>10^{\circ}$ east.

\section{Time budgets}

While our sample size in the number of individual birds is rather low, we could attain detailed data on time budgets of these individuals for the entire period of spring staging from acceleration data. Triaxial accelerometers can measure posture, speed and body movements (Wilson et al. 2008, Halsey \& White 2010) from which behavioural classes can be derived (Shamoun-Baranes et al. 2012). We trained a machine-learning model to classify four types of behaviour from acceleration data: inactive (sitting or standing still), grazing (pecking at grass tillers), active (walking) and flying. The model was trained and validated using a dataset of acceleration data with annotated behaviour, obtained from UvA-BiTS GPS/accelerometer tags attached to Barnacle Geese held in captivity, for which we simultaneously annotated behaviour (for further details on annotation and classification of behaviours see Lameris et al. 2018b). Time budgets were measured from the time between two GPS-fixes, from which the behaviour registered at the first data point was chosen as a representative of the behaviour between the two points. In this way we calculated for each goose the time spent grazing in $\mathrm{min} /$ day (grazing time) and the time spent flying in min/day per habitat.

\section{Habitat use}

From GPS-fixes we determined habitat use along the North Sea and Wadden Sea coast (Figure 1) as $\mathrm{min} /$ day during which a goose was grazing (as recorded by the accelerometer) in either pastures, salt marshes or other habitat. To determine habitat use, we used the CORINE database, which has a 100$\mathrm{m}^{2}$ resolution (Büttner et al. 2004, Büttner \& Kosztra 2007). For every GPS-fix, we determined the habitat in which a goose was grazing and distinguished between the following land use classes: salt marshes, freshwater marshes and pastures. Time spent in freshwater marshes was used to calculate total daily grazing time, but we did no further analyses on intake rates in this habitat (mean $\pm \mathrm{SD}$ fraction of total grazing time spent in freshwater marshes: $3 \pm 4 \%$ ). For some fixes where a goose was indicated as grazing, we encountered other classes of land use ( $6.5 \%$ of fixes with behaviour 'grazing'). Using a Google Earth map of the North Sea and Wadden Sea coast (Google), we determined whether this was due to an erroneous land cover classification $(5.7 \%$ of the fixes with behaviour 'grazing'), after which we corrected this by hand, or whether the grazing behaviour was classified incorrectly ( $0.8 \%$ of the fixes with behaviour 'grazing'). The latter was often the case when geese were sitting still on open sea, as waves would result in an accelerometer signal similar to grazing, and for these points we corrected the behaviour to resting (Shamoun-Baranes et al. 2011).

For each individual goose we determined its daily habitat use. For this we calculated the proportion of daily grazing time spent in either pastures or salt marshes. We then determined per day whether a goose was primarily grazing in pastures ( $>70 \%$ grazing time in pastures), salt marshes ( $>70 \%$ grazing time in salt marshes) or in a mixture of both habitats $(<70 \%$ but $>30 \%$ grazing time in 
pastures). For each individual we also calculated the total proportion of time which it spent grazing in salt marshes during the entire period from 1 January until departure.

\section{Disturbance movements}

Most short flights of geese are caused by disturbances (Owens 1977, Nolet et al. 2016), which makes the number of daily flights a potential measure for the disturbance levels experienced by geese. As the interval between GPS-fixes with acceleration data was too long to record most flight movements, we used distances covered between GPS-fixes to infer whether a goose had made a flight in between. When a goose moved a distance that was too long to be crossed without flying, it was counted as a flight movement, which we interpreted as a moment of disturbance. To differentiate between movements that could be crossed with and without flying we calculated the average speed in $\mathrm{m} / \mathrm{s}$ by dividing the great circle distance between two GPS-fixes by the duration of the interval between the two fixes. For this average speed we established a threshold value of $0.28 \mathrm{~m} / \mathrm{s}$, above which we assumed that the goose had made a flight movement between the GPS-fixes. We took this threshold from an analysis on a dataset with a high frequency of GPS-fixes (see Figure S1). We calculated the number of flights per goose per day, i.e. the number of intervals at which geese moved more than 0.28 $\mathrm{m} / \mathrm{s}$ on average.

\section{Food quality measurements}

Data on intake rates was collected between March and May 2016 on the Dutch Wadden island Schiermonnikoog $\left(53^{\circ} 30^{\prime} \mathrm{N}, 6^{\circ} 10^{\prime} \mathrm{E}\right.$, see Prins \& Ydenberg (1985) for detailed description). The island is a main wintering site for Barnacle Geese from the Russian breeding population (Ebbinge et al. 1975, van der Jeugd et al. 2001). There are two habitats in which Barnacle Geese mostly graze: pastures in the western and salt marshes in the eastern part of the island. Pastures are manured by farmers and have high primary productivity but also a variety of human disturbance, whereas the salt marshes have higher biodiversity due to lower productivity but are potentially richer in specific nutrients and have almost no human disturbance (Prins \& Ydenberg 1985, Bos 2002).

Sampling of food plants was done at three locations in pastures where the main food plant is Perennial Ryegrass Lolium perenne and three locations in salt marshes where the main food plant is Red Fescue Festuca rubra (Eichhorn et al. 2012). In both habitats, three enclosures $(0.5 \times 0.5 \times 0.5 \mathrm{~m})$ were placed in representative subsections to prevent grazing. Freshly grown vegetation from within the enclosures was collected every two weeks (six times in the March-May period) using tweezers to imitate grazing, after which the enclosures were moved by $5 \mathrm{~m}$ within the subsection. In the same fields and with a similar interval we measured defecation frequency by observing individual geese with a 30-60× telescope. Geese were observed until they were no longer visible or were disturbed. We only observed geese that had been grazing in an area for at least two hours, to be certain that vegetation of the current habitat was being passed through the digestive tract. Interval time (I, in min) was measured using a stopwatch. We corrected for potentially missed observations in our dropping intervals using the package intRvals in R (Dokter et al. 2017). The mean dropping interval in salt 
marshes was $277.1 \pm 59.1 \mathrm{~s}(n=26)$, and $295.7 \pm 44.6 \mathrm{~s}(n=48)$ in pastures. Dropping rates did not significantly differ between habitats $\left(t\right.$-test, $\left.t_{31.8}=-1.107, P=0.276\right)$. We therefore used a single average dropping interval for all analyses, namely $289.2 \mathrm{~s}$. After each series of observations, when the geese had left to roost, ten fresh droppings were collected.

For lab analyses we dried collected droppings and vegetation for $24 \mathrm{~h}$ at $60^{\circ} \mathrm{C}$. Individual droppings were weighed to the nearest $\mathrm{mg}$ after which samples were grinded. Nitrogen concentration was measured using a C:N analyser (Flash EA 1112 analyser, Thermo Fisher Scientific Inc., Waltham, USA). We chemically determined the mass concentration of acid detergent fibre content (ADF), an indigestible marker (following Prop \& Deerenberg 1991) using ANKOM Technology (Macedon, NY, USA) for a subset of samples ( 30 out of 56). To comprise a model to estimate ADF from near-infrared spectrometry (NIRS) measurements, we took NIRS measurements from all samples using a NIR spectrometer (Bruker MPA FT-NIR analyser with OPUS 7.0.129 software). From the chemical ADF measurements and a larger set of samples (food plants and droppings from Barnacle Geese collected at Kanin peninsula (RU, 68 $24^{\circ} \mathrm{N}, 44^{\circ} 99^{\prime} \mathrm{E}$ ) in 2002, Kolokolkova Bay in 2003 and 2015, Schiermonnikoog in 2004 and 2014-2016, Westplaat Buitengronden (NL, 51 ${ }^{\circ} 79^{\prime} \mathrm{N}, 4^{\circ} 13^{\prime} \mathrm{E}$ ) in 20152016, Eichhorn \& Lameris, unpubl. data) we could successfully comprise a model which we used to estimate ADF for all samples. We determined the fraction of inorganic matter by incineration of our samples in a $600^{\circ} \mathrm{C}$ stove for three hours and weighing the samples before and after. We then corrected all chemical measurements to ash free dry matter basis (AFDM).

\section{Fat and protein intake}

To make comparisons in the potential intake rates which geese encounter in pastures and salt marshes, we combine our data on grazing time, as taken from accelerometer data, and food quality to calculate deposition rates of nitrogen and fat. We acknowledge that our data on food quality is collected solely on Schiermonnikoog, while our data from tagged geese originates from across the entire Wadden Sea coast (Figure 1), and deposition rates may not reflect site-specific differences. However, we believe that our data is suitable to illustrate differences between habitats in such an analysis.

We calculated digestibility following Prop \& Black (1998), based on sets of ADF in food plants $\left(\mathrm{ADF}_{\text {food }}\right)$ and droppings $\left(\mathrm{ADF}_{\text {droppings }}\right)$. To correct for seasonal changes in digestibility (D), dropping mass $(\mathrm{W})$, nitrogen concentration in food plants $\left(\mathrm{N}_{\text {food }}\right)$ and nitrogen concentration in droppings $\left(\mathrm{N}_{\text {droppings }}\right)$ we ran linear regression analyses with day of year. Following Prop \& Black (1998) we calculated the potential amount of accumulated protein $\left(S_{\mathrm{p}}\right)$ and fat $\left(\mathrm{S}_{\mathrm{fat}}\right)$ from modelled values of $\mathrm{D}, \mathrm{W}, \mathrm{N}_{\text {food, }}, \mathrm{N}_{\text {droppings, }}$ combined with dropping intervals and grazing time (Table 1). To attain independent measures, we calculated these measures separately, and the amount of accumulated fat was not reduced by the energy needed to store proteins.

\section{Reproduction}

In the summer of 2015 at the breeding grounds in the Kolokolkova Bay, we searched for nests of birds with GPS/accelerometer tags using radio-detection. Lay dates, defined as the day at which the first 
egg was laid, were determined during the egg laying phase. For incomplete clutches found during egg laying, lay date was estimated by back calculating the date depending on the number of eggs in the nest, following van der Jeugd et al. (2009). Clutch size was determined during the mid-incubation period and was only recorded when the number of eggs in the nest remained constant between two visits to ensure that birds were no longer laying.

\section{Statistical analyses}

Analyses were limited to the spring staging period of Barnacle Geese during which we collected data on food quality (1 March - 15 May). We analysed our data using generalized linear models (GLMs) and linear mixed models (LMMs) in R v. 3.3.3 (R Core Team 2017) using the lme4 package (Bates et al. 2016). Daily grazing time and the daily number of flights were fitted in independent LMMs, with habitat, day of year and their interaction as fixed factors. Bird identity was added as a random factor to account for non-independence of the data. We tested for seasonal changes in food availability by fitting nitrogen content of food plants and droppings, digestibility of food plants and dropping mass in GLMs, with habitat and day of year as fixed factors. Data on protein and fat deposition were analysed with two independent LMMs with habitat, day of year and their interaction as fixed factors. We tested for correlation between the total proportion of grazing time in salt marshes with clutch size and nest initiation dates using GLMs.

\section{RESULTS}

We compiled location records for 23 individual female Barnacle Geese grazing throughout the spring of 2015 along the North Sea and Wadden Sea coast (Figure 1). Birds left this area between 28 April and 21 May. In January and February, Barnacle Geese were solely grazing in pastures (Figure 2). However, at the end of their winter staging period, Barnacle Geese became extremely variable in their habitat use as some individuals switched from grazing in pastures to salt marshes between February and March, while others remained in pastures until migratory departure or used a mixture of both habitats. For instance, the first date at which individual geese solely used salt marshes ranged between 7 March and 8 May, suggesting that the moment of habitat switch is highly variable between individuals (Figure 2). Four out of 23 geese made an abrupt switch from pastures to salt marshes and stayed in salt marshes until departure (Figure 2: devices 6135, 6110, 6102 and 6090), while another four geese stayed in pastures throughout the spring staging period (Figure 2: devices 6122, 6096, 6115 and 6115). However, 15 geese used a mixture of both habitats throughout the staging period (Figure 2: e.g. devices $6105,6132,6145$ and 6097).

\section{Grazing time and flight movements}

There was a significant positive effect of grazing time with day of year, indicating that all Barnacle Geese increased their daily grazing time as spring progressed (LMM: $2.8 \pm 0.17 \mathrm{~min} /$ day of year, $\chi^{2}=$ $377.12, P<0.001$; Figure 3A). However, geese primarily grazing in salt marshes showed a larger 
increase in daily grazing time with day of year than geese primarily grazing in pastures (LMM: interaction day of year $\times$ habitat use: $\chi^{2}=8.75, P=0.003$, pastures: $2.84 \pm 0.17 \mathrm{~min} /$ day of year, salt marshes: $3.88 \pm 0.52 \mathrm{~min} /$ day of year; Figure $3 \mathrm{~A}$ ).

A significant positive effect of daily number of flights with day of year indicated that all Barnacle Geese made more flights per day later in spring (LMM: $0.02 \pm 0.01$ flights/day of year, $\chi^{2}=$ $6.76, P=0.009)$. Geese primarily staging in pastures showed a larger increase in the daily number of flights than geese primarily staging in salt marshes (LMM: interaction day of year $\times$ habitat use: $\chi^{2}=$ 23.88, $P<0.001$, pastures: $0.02 \pm 0.01$ flights/day of year, salt marshes: $-0.02 \pm 0.01$ flights/day of year; Figure 3B).

\section{Food quality}

Digestibility of food plants did not change with day of year in pastures (GLM: $t=-0.118, n=9, P=$ 0.91 ), nor in salt marshes (GLM: $t=0.183, n=7, P=0.86$ ), but was higher in pastures compared to salt marshes (mean $\pm \mathrm{SD}$, pastures: $0.52 \pm 0.04 \%$, salt marshes: $0.45 \pm 0.08 \%$, GLM habitat: $F_{1,13}=$ 5.804, $P=0.03$, day of year: $F_{1,13}=0.002, P=0.96$; Figure 4A). Nitrogen content in food plants decreased with day of year, both in pastures (GLM: $-0.02 \pm 0.01 \%, t=-3.32, n=19, P=0.004$ ) and in salt marshes (GLM: $-0.02 \pm 0.01 \%, t=-3.63, n=18, P=0.002$ ), but was on average higher in pastures (mean $\pm \mathrm{SD}$, pastures: $4.98 \pm 0.92 \%$, salt marshes: $3.47 \pm 0.86 \%$, GLM habitat: $F_{1,34}=$ 41.272, $P<0.001$, day of year: $F_{1,35}=28.210, P<0.001$; Figure 4B). Further analyses on food quality are reported in the supplemental information (Figure S2).

\section{Fat and protein intake}

All Barnacle Geese increased their daily deposition of protein (LMM: $0.58 \pm 0.02 \mathrm{~g} /$ day of year, $\chi^{2}=$ $1980.3, P<0.001$; Figure 5A $)$ and fat $\left(0.28 \pm 0.02 \mathrm{~g} /\right.$ day of year, $\chi^{2}=510.45, P<0.001$; Figure 5B) over time with the progress of spring. Compared to geese grazing in salt marshes, geese grazing in pastures showed higher potential protein deposition rates (LMM: interaction habitat use $\times$ day of year: $\chi^{2}=33.81, P<0.001$, pastures: $0.59 \pm 0.02 \mathrm{~g}$ /day, salt marshes: $0.50 \pm 0.03 \mathrm{~g}$ /day; Figure $5 \mathrm{~A}$ ). On the other hand, fat deposition rates appeared to increase faster with day of year in salt marshes (LMM: interaction day of year $\times$ habitat use: $\chi^{2}=88.10, P<0.001$, pastures: $0.27 \pm 0.02 \mathrm{~g} /$ day of year, salt marshes: $0.56 \pm 0.05 \mathrm{~g} /$ day; Figure $5 \mathrm{~B}$ ), but a lower starting value (habitat use: $\chi^{2}=64.23, P<0.001$, pastures: $-22.57 \pm 1.74 \mathrm{~g}$, salt marshes: $-58.15 \pm 3.37 \mathrm{~g}$ ) suggests that the difference between habitats in fat deposition may be minimal.

\section{Reproduction}

The total proportion of grazing time which geese spend in salt marshes did not show a correlation with nest initiation date (GLM: $\left.F_{1,16}=1.94, P=0.182\right)$, nor with clutch size $\left(F_{1,16}=0.0002, P=\right.$ 0.990). 
We assessed which factors may drive a habitat switch by combining detailed location and behavioural data of female Barnacle Geese equipped with GPS/accelerometer tags with data on food quality and intake rates of fat and protein. First, we find high variability in pre-migratory habitat use during early spring which contrasts strongly with previous observations. Secondly, we find that Barnacle Geese grazing in pastures spend less time grazing, made more flights per day and attained a faster potential protein deposition than geese grazing in salt marshes. We conclude that pastures provide geese with high-quality food and discuss why some geese are still using salt marshes.

\section{Pre-migratory habitat use}

We find that almost all the individual geese that we tracked changed their habitat use from no use of salt marshes during winter to at least some use of salt marshes during spring staging. However, from early March until migratory departure we find large individual variation in habitat use. Some geese did not switch from pastures to salt marshes, with some individuals using a mixture of both habitats throughout the entire period of spring staging. This observation contrasts with the strong synchronisation in switching behaviour found in other studies (Prins \& Ydenberg 1985, Bos \& Stahl 2003). Our results are supported by van der Jeugd et al. (2001) who observed that small groups of geese continued grazing in pastures until migratory departure and predicted that pastures will become more important with increasing Barnacle Geese populations. To explore why some geese make such a habitat switch, while others continue to use pastures until departure for migration, we investigate the energetic costs and gains of foraging in pastures and salt marshes.

\section{Energy intake}

We find that food plants in salt marshes had a lower nutritional value and digestibility compared to pastures. Individual geese grazing in salt marshes spent more time grazing compared to geese grazing in pastures, which suggests that geese staging in salt marshes must make up for the lower intake rate by grazing for longer periods of time. However, we find that this is only partly true. Barnacle Geese grazing in salt marshes achieved lower intake rates of protein and fat, but the difference was only slight. An increase in grazing to make up for lower food quality has been observed for Brent Geese Branta bernicla grazing in salt marshes (Dokter et al. 2018b) and Pink-footed Geese, which spent $80 \%$ of their time grazing in pastures, but only $54 \%$ in newly sown barley fields where intake rates were higher (Madsen 1985). Due to the relatively low fibre content and high digestibility of food plants in pastures, geese can attain their daily energy requirements at a faster rate than in salt marshes (Fox et al. 2016). According to Prop \& Deerenberg (1991), preferred food plants in salt marshes also have a patchier distribution whereas food plants in pastures have a homogeneous distribution. These differences in food plant distribution may not only affect grazing time but may also increase competition between individuals in salt marshes (Prop \& Deerenberg 1991, Dokter et al. 2018b).

Geese grazing in salt marshes attained slightly lower fat and protein deposition than geese grazing in pastures. While energy is most efficiently stored as fat, protein is vital for the development 
of flight muscles, formation of eggs and metabolic processes (Ydenberg \& Prins 1981, Jenni \& JenniEiermann 1998, Meijer \& Drent 1999). This demand for protein is thought to drive the pre-migratory habitat switch observed in many species of geese, as pastures and other agricultural crops have been considered to fail to provide sufficient proteins (Madsen 1985, Prins \& Ydenberg 1985, Prop \& Black 1998) or have an imbalanced amino acid composition (Prop \& Black 1998). However, Eichhorn et al. (2012) found no differences in protein content between food plants Festuca rubra and Lolium perene in salt marshes and pastures respectively, and subsequently no differences in body composition of Barnacle Geese using these respective habitats. This leads to the conclusion that pastures offer geese a profitable food source without impaired protein deposition (Eichhorn et al. 2012). We also found that geese in pastures are able to deposit more protein stores, despite the fact that geese spent less time grazing in this habitat. Pastures are known to provide food plants which are highly digestible and high in protein concentration (van Eerden et al. 2005, Eichhorn et al. 2012, Dokter et al. 2018a, 2018b), as we underline in this study. Nevertheless, differences in fat and protein deposition do not seem to carry over into reproductive output, as we do not find differences in clutch size and nest initiation date between individuals that differed in habitat use prior to migration. This suggests that geese which switch to salt marshes prior to migration do not suffer from potential protein deficiency. For Brent Geese, the timing of migration of birds primarily staging in salt marshes was delayed relative to birds staging in pastures, a difference which only disappeared close to arrival on the breeding grounds (Dokter et al. 2018b). Geese may be able to compensate for smaller protein stores by additional feeding in salt marshes while staging or at stopover sites during migration (Prop \& Spaans 2004).

When geese staging in agricultural pastures experience better feeding conditions during the entire spring period, the question arises as to why some geese still switch to apparently suboptimal salt marsh habitat. Although such a switch may be explained as a tradition, passed on by previous generations of geese (van der Jeugd et al. 2001, Fox et al. 2005), it can potentially also be explained by differences in energetic costs between foraging in these two habitats.

\section{Energetic costs}

Geese grazing in pastures were more frequently disturbed, as indicated by higher numbers of daily flights, which would result in higher flight costs and consequently higher daily energy expenditure. As our method of 30-min intervals did not allow us to distinguish between longer and shorter flights, we cannot rule out that the difference in the number of daily flights also reflects differences in roost flights between geese grazing in pastures and salt marshes. Barnacle Geese grazing in salt marshes can roost at these same sites or on close-by open water, while geese grazing in pastures often need to cover larger distances from their grazing grounds to their night roost. However, it is well established that salt marshes provide a more disturbance-free habitat. For Brent Geese staging in Denmark, energetic costs in pastures were higher than in salt marshes and aquatic habitats due to increased time spent flying, involvement in aggressive interactions and alertness (Clausen et al. 2013). Also, Brent Geese in England were more likely to be disturbed in pastures than in salt marshes, mainly by humans (Riddington et al. 1996). To exploit high-quality food in pastures, geese probably need to allow for 
relatively high levels of disturbance, whereas geese in lower-quality salt marshes are likely to experience lower levels of disturbance. This suggests the existence of a trade-off, either to forage in habitat with high food quality but high energy expenditure, or habitat with less energy expenditure but also reduced food quality. Such a trade-off has also been shown for Redshanks Tringa totanus, which prefer to forage in areas which provide them with lower energy intake but also lower risk of being taken as prey by a Sparrowhawk Accipiter nisus (Cresswell 1994). Under such a trade-off, the individual variation in pre-migratory habitat use of Barnacle Geese may be explained by differences in body condition or social status. Geese which cannot compensate for the energetic costs associated with a higher number of daily flight movements - e.g. individuals in poor condition or inexperienced birds (Nolet et al. 2016) - may need to switch to a less disturbed habitat at an individually variable optimal moment. Indeed, high levels of disturbance are known to affect habitat selection in geese, with geese tending to move towards habitats with lower levels of disturbance (Nolet et al. 2016).

We suggest that individual variation in pre-migratory habitat use may be explained by a trade-off in net energetic returns, with higher gains but also higher costs in pastures versus lower gains but lower costs in salt marshes. Hence, the costs and benefits of pre-migratory habitat use by Barnacle Geese may be weighted on the level of the individual or small groups.

\section{Population increase and management implications}

Many populations of geese and other herbivorous waterfowl have increased over the past 50 years (Fox et al. 2010), simultaneously with a shift in increasing use of agricultural habitats during winter staging (van Eerden et al. 2005, Fox et al. 2016). Fertilized pastures and other agricultural crops provide geese with high intake rates and have, amongst other management measures (e.g. reduced hunting), allowed for increasing populations (van Eerden et al. 1996, Gauthier et al. 2005, Si et al. 2011). The present study additionally shows that pastures provide pre-migratory Barnacle Geese with high-quality foraging habitat, and that differences in net energy gain between pastures and salt marshes are relatively small. The dependency on man-made habitats makes populations vulnerable to future land-use changes (Eichhorn et al. 2012). However, if individuals can trade-off costs and benefits among different habitat types, then geese are not dependent on pastures or salt marshes but are instead capable of utilizing different habitats based on the local conditions in terms of intake rate and disturbance.

\section{ACKNOWLEDGEMENTS}

We thank Natuurmonumenten for access to national park Schiermonnikoog, and families Talsma and Visser for access to their pastures. Bart Nolet and Ronald Ydenberg gave helpful advice on the analysis and an earlier version of the manuscript. We thank Sander Moonen for useful discussion, Willem Bouten for helping with data analysis, Gracie Adams for assisting with fieldwork, Peter de Vries and Chiel Boom for assistance with GIS analysis and Willem Nieuwenhuis for his help with the 
programming. Two anonymous reviewers gave helpful comments to an earlier version of the manuscript.

\section{REFERENCES}

Abraham K.F., Jefferies R.L. \& Alisauskas R.T. 2005. The dynamics of landscape change and Snow Geese in mid-continent North America. Glob. Chang. Biol. 11: 841-855.

Alerstam T., Hedenström A. \& Åkesson S. 2003. Long-distance migration: evolution and determinants. Oikos 103: 247-260.

Bates D., Mächler M., Bolker B. \& Walker S. 2016. Fitting linear mixed-effects models using lme4. J. Stat. Softw. 67: 1-48.

Bédard J. \& Gauthier G. 1989. Comparative energy budgets of Greater Snow Geese. Ardea 77: 3-20.

Blaxter K.L. 1989. Energy metabolism in animals and man. Cambridge University Press, Cambridge.

Bos D. 2002. Grazing in coastal grasslands: Brent Geese and facilitation by herbivory. PhD Thesis, University of Groningen, The Netherlands, pp. 8-22.

Bos D. \& Stahl J. 2003. Creating new foraging opportunities for Dark-Bellied Brent Branta bernicla and Barnacle Geese Branta leucopsis in spring-insights from a large-scale experiment. Ardea 91: 153-166.

Bouten W., Baaij E.W., Shamoun-Baranes J. \& Camphuysen K.C.J. 2013. A flexible GPS tracking system for studying bird behaviour at multiple scales. J. Ornithol. 154: 571-580.

Büttner G. \& Kosztra B. 2007. CLC2006 technical guidelines.

Büttner G., Feranec J., Jaffrain G., Mari L., Maucha G. \& Soukup T. 2004. The Corine Land Cover 2000 Project. EARSeL eProceedings 3: 331-346.

Clausen K.K., Clausen P., Fox A.D., Fælled C.C. \& Madsen J. 2013. Varying energetic costs of Brent Geese along a continuum from aquatic to agricultural habitats: the importance of habitatspecific energy expenditure. J. Ornithol. 154: 155-162.

Cresswell W. 1994. Age-dependent choice of redshank (Tringa totanus) feeding location: profitability or risk? J. Anim. Ecol. 63: 589-600.

Dokter A.M., van Loon E.E., Fokkema W., Lameris T.K., Nolet B.A. \& van der Jeugd H.P. 2017. Analyzing time-ordered event data with missed observations. Ecol. Evol. 7: 7362-7369.

Dokter A.M., Fokkema W., Bekker S.K., Bouten W., Ebbinge B.S., Müskens G., Olff H., van der Jeugd H.P. \& Nolet B.A. 2018a. Body stores persist as fitness correlate in a long-distance migrant released from food constraints. Behav. Ecol. 29: 1157-1166.

Dokter A.M., Fokkema W., Ebbinge B.S., Olff H., van der Jeugd H.P. \& Nolet B.A. 2018b. Agricultural pastures challenge the attractiveness of natural saltmarsh for a migratory goose. $\mathrm{J}$. Appl. Ecol. 55: 2707-2718.

Drent R.H. \& Prins H.H.T. 1987. The herbivore as prisoner of its food supply. In: Disturbance in grasslands. Springer, Dordrecht, The Netherlands, pp. 131-147. 
Drent R.H. \& Daan S. 1980. The prudent parent: energetic adjustments in avian breeding. Ardea 68: $225-252$.

Drent R.H., Eichhorn G., Flagstad A., van der Graaf A.J., Litvin K.E. \& Stahl J. 2007. Migratory connectivity in Arctic geese: Spring stopovers are the weak links in meeting targets for breeding. J. Ornithol. 148: 501-514.

Ebbinge B.S. \& Spaans B. 1995. The importance of body reserves accumulated in spring staging areas in the temperate zone for breeding in Dark-bellied Brent Geese Branta b. bernicla in the high Arctic. J. Avian Biol. 26: 105-113.

Ebbinge B.S., Canters K. \& Drent R. 1975. Foraging routines and estimated daily food intake in Barnacle Geese wintering in the northern Netherlands. Wildfowl 26: 5-19.

Eichhorn G., Meijer H., Oosterbeek K. \& Klaassen M. 2012. Does agricultural food provide a good alternative to a natural diet for body store deposition in geese? Ecosphere 3: 1-13.

Fox A.D., Madsen J., Boyd H., Kuijken E., Norriss D.W., Tombre I.M. \& Stroud D.A. 2005. Effects of agricultural change on abundance, fitness components and distribution of two arctic-nesting goose populations. Glob. Chang. Biol. 11: 881-893.

Fox A.D., Ebbinge B.S., Mitchell C., Heinicke T., Aarvak T., Colhoun K., Clausen P., Dereliev S., Faragö S., Koffijberg K., Kruckenberg H., Loonen M.J.J.E., Madsen J., Mooij J., Musil P., Nilsson L., Pihl S. \& van der Jeugd H.P. 2010. Current estimates of goose population sizes in western Europe, a gap analysis and an assessment of trends. Ornis Svecica 20: 115-127.

Fox A.D., Elmberg J., Tombre I.M. \& Hessel R. 2016. Agriculture and herbivorous waterfowl: a review of the scientific basis for improved management. Biol. Rev. 92: 854-877.

Fryxell J.M. 1991. Forage quality and aggregation by large herbivores. Am. Nat. 138: 478-498. Fryxell J.M. \& Sinclair A.R.E. 1988. Causes and consequences of migration by large herbivores. Trends Ecol. Evol. 3: 237-241.

Gauthier G., Giroux J.F., Reed A., Bechet A. \& Bélanger L.U.C. 2005. Interactions between land use, habitat use, and population increase in Greater Snow Geese: what are the consequences for natural wetlands? Glob. Chang. Biol. 11: 856-868.

Halsey L.G. \& White C.R. 2010. Measuring energetics and behaviour using accelerometry in Cane Toads Bufo marinus. PLoS One 5: e10170.

Jenni L. \& Jenni-Eiermann S. 1998. Fuel supply and metabolic constraints in migrating birds fuel supply and metabolic constraints in migrating birds. J. Avian Biol. 29: 521-528.

Klaassen M. \& Biebach H. 1994. Energetics of fattening and starvation in the long-distance migratory Garden Warbler Sylvia borin during the migratory phase. J. Comp. Physiol. B. 164: 362-371.

Klaassen M., Hahn S., Korthals H. \& Madsen J. 2017. Eggs brought in from afar: Svalbard-breeding Pink-footed Geese can fly their eggs across the Barents Sea. J. Avian Biol. 48: 173-179.

Kölzsch A., Bauer S., de Boer R., Griffin L., Cabot D., Exo K.M., van der Jeugd H.P. \& Nolet B.A. 2015. Forecasting spring from afar? Timing of migration and predictability of phenology along different migration routes of an avian herbivore. J. Anim. Ecol. 84: 272-283. 
Lameris T.K., Kölzsch A., Dokter A.M., Nolet B.A. \& Müskens G.J.D.M. 2017. A novel harness for attaching tracking devices to migratory geese. Goose Bull.: 25-30.

Lameris T.K., Müskens G.J.D.M., Kölzsch A., Dokter A.M., van der Jeugd H.P. \& Nolet B.A. 2018a. Effects of harness-attached tracking devices on survival, migration, and reproduction in three species of migratory waterfowl. Anim. Biotelem. 6: 7.

Lameris T.K., van der Jeugd H.P., Eichhorn G., Dokter A.M., Bouten W., Boom M.P., Litvin K.E., Ens B.J. \& Nolet B.A. 2018b. Arctic geese tune migration to a warming climate but still suffer from a phenological mismatch. Curr. Biol. 28: 2467-2473.

Lindström A. 1991. Maximum fat deposition rates in migrating birds. Ornis Scand. 22: 12-19.

Lindström A. \& Piersma T. 1993. Mass changes in migrating birds: the evidence for fat and protein storage re-examined. Ibis 135: 70-78.

Madsen J. 1985. Relations between change in spring habitat selection and daily energetics of Pinkfooted Geese Anser brachyrhynchus. Ornis Scand. 16: 222-228.

Mckay H.V, Bishop J.D. \& Ennis D.C. 1994. The possible importance of nutritional requirements for Dark-Bellied Brent Geese in the seasonal shift from winter cereals to pasture. Ardea 82: 123 132.

McWilliams S.R. \& Karasov W.H. 2001. Phenotypic flexibility in digestive system structure and function in migratory birds and its ecological significance. Comp. Integr. Physiol. 128: $577-$ 591.

Meijer T. \& Drent R. 1999. Re-examination of the capital and income dichotomy in breeding birds. Ibis 141: 399-414.

Nolet B.A., Bevan R.M., Klaassen M., Langevoord O. \& van der Heijden Y.G.J.T. 2002. Habitat switching by Bewick's Swans: maximization of average long-term energy gain? J. Anim. Ecol. 71: 979-993.

Nolet B.A., Kölzsch A., Elderenbosch M. \& van Noordwijk A.J. 2016. Scaring waterfowl as a management tool: how much more do geese forage after disturbance? J. Appl. Ecol. 53: 14131421.

Owens N.W. 1977. Responses of wintering Brent Geese to human disturbance. Wildfowl 28: 5-14.

Piersma T. 1998. Phenotypic flexibility during migration: optimization of organ size contingent on the risks and rewards of fuelling and flight? J. Avian Biol. 29: 511-520.

Prins H.H.T. \& Ydenberg R.C. 1985. Vegetation growth and a seasonal habitat shift of the Barnacle Goose (Branta leucopsis). Oecol. 66: 122-125.

Prop J. \& Black J.M. 1998. Food intake, body reserves and reproductive success of Barnacle Geese Branta leucopsis staging in different habitats. Nor. Polarinstitutt Skr. 200: 175-193.

Prop J. \& Deerenberg C. 1991. Spring staging in Brent Geese Branta bernicla: feeding constraints and the impact of diet on the accumulation of body reserves. Oecol. 87: 19-28.

Prop J. \& Spaans B. 2004. Body stores in pre-migratory Brent Geese: the consequence of habitat choice on protein deposition. In: J. Prop (ed.) Food finding: on the trail to successful 
reproduction in migratory geese. $\mathrm{PhD}$ Thesis, University of Groningen, The Netherlands, pp. $71-86$

Prop J. \& Vulink T. 1992. Digestion by Barnacle Geese in the annual cycle: the interplay between retention time and food quality. Funct. Ecol. 6: 180-189.

R Core Team. 2017. R: A language and environment for statistical computing. R foundation for statistical computing, Vienna, Austria.

Riddington R., Hassall M., Lane S.J., Turner P.A. \& Walters R. 1996. The impact of disturbance on the behaviour and energy budgets of Brent Geese Branta b. bernicla. Bird Study 43: 269-279.

Schmidt-Nielsen K. 1975. Animal physiology: adaptation and environment. Cambridge University Press.

Sedinger J.S. 1997. Adaptions to and consequences of an herbivorous diet in grouse and waterfowl. Condor 99: 314-326.

Shamoun-Baranes J., Bouten W., Camphuysen C.J. \& Baaij E. 2011. Riding the tide: Intriguing observations of gulls resting at sea during breeding. Ibis 153: 411-415.

Shamoun-Baranes J., Bom R., van Loon E.E., Ens B.J., Oosterbeek K. \& Bouten W. 2012. From sensor data to animal behaviour: an Oystercatcher example. PLoS One 7: e37997.

Si Y., Skidmore A.K., Wang T., de Boer W.F., Toxopeus A.G., Schlerf M., Oudshoorn M., Zwerver S., van der Jeugd H.P., Exo K.M. \& Prins H.H.T. 2011. Distribution of Barnacle Geese Branta leucopsis in relation to food resources, distance to roosts, and the location of refuges. Ardea 99: 217-226.

Simon O. 1989. Metabolism of proteins and amino acids. In: Bock H.D., Eggum B.O., Low A.G., Simon O. \& Zebrowska T. (eds) Protein metabolism in farm animals. Oxford University Press Oxford, pp. 273-366.

van der Graaf A.J., Stahl J., Bos D. \& Drent R.H. 2001. Influence of wind exposure and temperature on energy expenditure and site choice in Brent and Barnacle Geese. In: J. Stahl (ed.) Limits to the co-occurrence of avian herbivores. How geese share scarce resources. PhD Thesis, University of Groningen, The Netherlands, pp. 121-152.

van der Graaf A.J., Stahl J., Klimkowska A., Bakker J.P. \& Drent R.H. 2006. Surfing on a green wave - how plant growth drives spring migration in the Barnacle Goose Branta leucopsis. Ardea 94: $567-577$.

van der Jeugd H.P., Olthoff M.P. \& Stahl J. 2001. Breeding range translates into staging site choice: Baltic and arctic barnacle geese Branta leucopsis use different habitats at a Dutch Wadden Sea island. Ardea 89: 253-265.

van der Jeugd H.P., Gurtovaya E., Eichhorn G., Litvin K.Y., Mineev O.Y. \& van Eerden M. 2003. Breeding Barnacle Geese in Kolokolkova Bay, Russia: Number of breeding pairs, reproductive success and morphology. Polar Biol. 26: 700-706.

van der Jeugd H.P., Eichhorn G., Litvin K.E., Stahl J., Larsson K., van der Graaf A.J. \& Drent R.H. 2009. Keeping up with early springs: rapid range expansion in an avian herbivore incurs a mismatch between reproductive timing and food supply. Glob. Chang. Biol. 15: 1057-1071. 
van Eerden M.R., Zijlstra M., van Roomen M. \& Timmerman A. 1996. The response of Anatidae to changes in agricultural practice: long-term shifts in the carrying capacity of wintering waterfowl. Gibier Faune Sauvage 13: 681-707.

van Eerden M.R., Drent R.H., Stahl J. \& Bakker J.P. 2005. Connecting seas: Western Palaearctic continental flyway for water birds in the perspective of changing land use and climate. Glob. Chang. Biol. 11: 894-908.

Vickery J.A., Sutherland W.J., Watkinson A.R., Rowcliffe J.M. \& Lane S.J. 1995. Habitat switching by Dark-bellied Brent Geese Branta b. bernicla in relation to food depletion. Oecol. 103: 499508.

Warnock N. 2010. Stopping vs. staging: the difference between a hop and a jump. J. Avian Biol. 41: $621-626$.

Wilson R., Shepard E. \& Liebsch N. 2008. Prying into the intimate details of animal lives: use of a daily diary on animals. Endanger. Species Res. 4: 123-137.

Ydenberg R.C. \& Prins H.H.T. 1981. Spring grazing and the manipulation of food quality by Barnacle Geese. J. Appl. Ecol. 18: 443-453.

Zwarts L., Ens B.J., Kersten M. \& Piersma T. 1990. Moult, mass and flight range of waders ready to take off for long-distance migrations. Ardea 78: 339-364.

\section{SAMENVATTING}

Trekvogels hebben aanzienlijke energiereserves nodig om in het voorjaar hun noordelijke broedgebieden te bereiken. Om voorafgaand aan vertrek voldoende energie voorraden aan te leggen, hebben vogels hoge opnamesnelheden nodig die bereikt kunnen worden door een voedselbron van hoge kwaliteit te exploiteren. Tijdens deze periode van extreme energiebehoefte, komt het regelmatig voor dat dieren veranderingen in voedselkwaliteit volgen, bijvoorbeeld door een hoogwaardiger habitat en/of voedselbron te gebruiken. Van Brandganzen Branta leucopsis die overwinteren langs de Nederlandse Waddenzeekust is bekend dat deze in de loop van het voorjaar hun foerageeractiviteiten verschuiven van agrarisch grasland in polders naar meer natuurlijk grasland op kwelders. Er is gesuggereerd dat Brandganzen veranderingen in de eiwitwaarde van het gras volgen, die afneemt in polders naarmate het voorjaar vordert. Met deze studie proberen we de factoren te achterhalen die Brandganzen ertoe bewegen van habitat te veranderen, door opnamesnelheden van vet en eiwit te schatten voor individuele ganzen. Brandganzen waren zeer variabel in hun habitatgebruik, zowel in het absolute gebruik van kwelders als in het moment waarop ganzen verschoven van polder naar kwelder. Op de kwelder hadden ganzen meer graastijd nodig om in hun energiebehoeften te kunnen voorzien en maakte ganzen minder vliegbewegingen, mogelijk als gevolg van minder verstoringen ten opzichte van de polder. Door de graastijd te verhogen en het aantal vliegbewegingen te verminderen kunnen ganzen compenseren voor de lagere voedselkwaliteit op de kwelder. Onze resultaten laten zien dat Brandganzen een afweging maken tussen hoge opnamesnelheden en hoge kosten in de polder en lage opnamesnelheden en lage kosten op de kwelder. 


\section{FIGURE CAPTIONS}

Figure 1. Map showing positions of 23 female Barnacle Geese equipped with UvA-BiTS GPS/accelerometer tags during January-May in 2015. Orange areas indicate positions in pastures and dark blue areas indicate positions in salt marshes.

Figure 2. Habitat use of 23 tracked female Barnacle Geese. For each goose the proportion of time spent in pastures is shown for each day of year between 1 January and 15 May in 2015. Grey dotted lines indicate the $30 \%$ and $70 \%$ thresholds for determining daily habitat use (see Methods). Colours indicate daily habitat use where orange indicates pastures, green indicates a mixture of habitats and dark blue indicates salt marshes. Numbers above the plots refer to UvA-BiTS GPS/accelerometer tag IDs attached to the geese. Plots of individual geese are ordered from low use of salt marshes to extensive use of salt marshes.

Figure 3. Means and standard deviations drawn as ribbons of (A) grazing time in min/day and (B) daily number of flight movements of Barnacle Geese staging in pastures (orange) and salt marshes (dark blue). Grey dashed lines indicate the period during which we sampled food plants. For grazing time and flight movements in salt marshes, we only plotted data after 10 April, as before this date geese only spent $0.05 \%$ of the total recorded days in salt marshes.

Figure 4. Plots showing (A) digestibility of food plants (\%) and (B) dropping mass (g) with day of year in pastures (orange) and salt marshes (dark blue). Lines show linear regressions which are significant, whereas the dashed lines show non-significant linear regressions.

Figure 5. Means and standard deviations drawn as ribbons of mean (A) protein and (B) fat deposition in g/day of Barnacle Geese grazing in pastures (orange) and salt marshes (dark blue). Grey dashed line indicates the threshold at which geese have positive fat deposition. For protein and fat deposition in salt marshes, we only plotted data after 10 April, as before this date geese only spent $0.05 \%$ of the total recorded days in salt marshes. 


\section{TABLES}

Table 1. Overview of parameters and their formulas used for calculating potential intake rates of protein and fat of Barnacle Geese. Formulas were obtained from Prop \& Black (1998). ADF is the mass concentration of acid detergent fibre content for food plants and droppings, $\mathrm{W}$ is dropping mass in grams, $\mathrm{I}$ is the dropping interval in seconds, $\mathrm{N}$ is the nitrogen concentration of food plants and droppings, grazing time is the total time spend grazing in $\mathrm{min} /$ day.

\begin{tabular}{|c|c|c|}
\hline Parameter & Unit & Formula or description \\
\hline Digestibility (D) & $\%$ & $\begin{array}{l}\mathrm{D}=100 \times\left(1-\mathrm{ADF}_{\text {food }}\right. \\
\left./ \mathrm{ADF}_{\text {droppings }}\right)\end{array}$ \\
\hline $\begin{array}{l}\text { Ingestion rate organic matter } \\
\text { (IR) }\end{array}$ & $\mathrm{g} / \mathrm{min}$ & $\mathrm{IR}=(\mathrm{W} / \mathrm{I}) \times(100 /(100-\mathrm{D}))$ \\
\hline Digestion rate (IRD) & $\mathrm{g} / \mathrm{min}$ & $\mathrm{IRD}=\mathrm{IR} \times(\mathrm{D} / 100)$ \\
\hline $\begin{array}{l}\text { Retention efficiency of } \\
\text { Nitrogen (AN) }\end{array}$ & $\%$ & $\mathrm{AN}=\mathrm{D} \times\left(\mathrm{N}_{\text {droppings }} / \mathrm{N}_{\text {food }}\right)$ \\
\hline $\begin{array}{l}\text { Ingestion rate of Nitrogen } \\
\text { (IRN) }\end{array}$ & $\mathrm{g} / \mathrm{min}$ & $\mathrm{IRN}=\mathrm{IR} \times\left(\mathrm{N}_{\text {food }} / 100\right)$ \\
\hline $\begin{array}{l}\text { Retention rate of Nitrogen } \\
\text { (IRAN) }\end{array}$ & $\mathrm{g} / \mathrm{min}$ & $\begin{array}{l}\mathrm{IRAN}=\mathrm{IR} \times\left(\mathrm{N}_{\text {food }} / 100\right) \times \\
(\mathrm{AN} / 100)\end{array}$ \\
\hline $\begin{array}{l}\text { Excretion rate of Nitrogen } \\
(E R N)\end{array}$ & $\mathrm{g} / \mathrm{min}$ & $\mathrm{ERN}=(\mathrm{W} / \mathrm{I}) \times\left(\mathrm{N}_{\text {droppings }} / 100\right)$ \\
\hline Accumulation of Nitrogen $\left(\mathrm{S}_{\mathrm{N}}\right)$ & g/day & $\begin{array}{l}\mathrm{SN}=(\mathrm{IRAN} \times \text { grazing time })- \\
\mathrm{ERN}_{0} \times(24 \times 60-\text { grazing time })\end{array}$ \\
\hline $\begin{array}{l}\text { Accumulated amount of protein } \\
\text { stores }\left(\mathrm{S}_{\mathrm{P}}\right)\end{array}$ & g/day & $\mathrm{S}_{\mathrm{P}}=\mathrm{S}_{\mathrm{N}} \times 6.25^{*}$ \\
\hline $\begin{array}{l}\text { Daily energy expenditure } \\
\text { (DEE) }\end{array}$ & $\mathrm{kJ} /$ day & $\begin{array}{l}991 \mathrm{~kJ} \text { (van der Graaf et al. } \\
\text { 2001) }\end{array}$ \\
\hline $\begin{array}{l}\text { Energy content of metabolized } \\
\text { matter (EM) }\end{array}$ & $\mathrm{kJ} / \mathrm{g}$ & 18.6 (Prop et al. 2004) \\
\hline Energy content of protein $\left(E_{\text {prot }}\right)$ & $\mathrm{kJ} / \mathrm{g}$ & 18 (Schmidt-Nielsen 1975) \\
\hline $\begin{array}{l}\text { Efficiency of protein synthesis } \\
\left(\mathrm{EFF}_{\text {prot }}\right)\end{array}$ & $\%$ & 0.61 (Simon 1989) \\
\hline $\begin{array}{l}\text { Energy available for } \\
\text { accumulating fat stores }\left(\mathrm{PE}_{\mathrm{fat}}\right)\end{array}$ & $\mathrm{kJ} /$ day & $\begin{array}{l}\mathrm{PE}_{\text {fat }}=(\mathrm{IRD} \times \mathrm{EM} \times \text { Active })- \\
\mathrm{DME}\end{array}$ \\
\hline
\end{tabular}


Energy content of fat $\left(\mathrm{E}_{\mathrm{fat}}\right) \quad \mathrm{kJ} / \mathrm{g}$

Efficiency of fat synthesis $\quad \%$ $\left(\mathrm{EFF}_{\mathrm{fat}}\right)$

Accumulated amount of fat $\quad \mathrm{g} /$ day stores $\left(\mathrm{S}_{\mathrm{fat}}\right)$
39.5 (Schmidt-Nielsen 1975)

0.77 (Simon 1989)

$$
\mathrm{S}_{\text {fat }}=\left(\mathrm{PE}_{\text {fat }} \times \mathrm{EFF}_{\text {fat }}\right) / \mathrm{E}_{\text {fat }}
$$

*assuming $16 \%$ of protein is composed of nitrogen (Blaxter 1989). 
FIGURES



Figure 1 


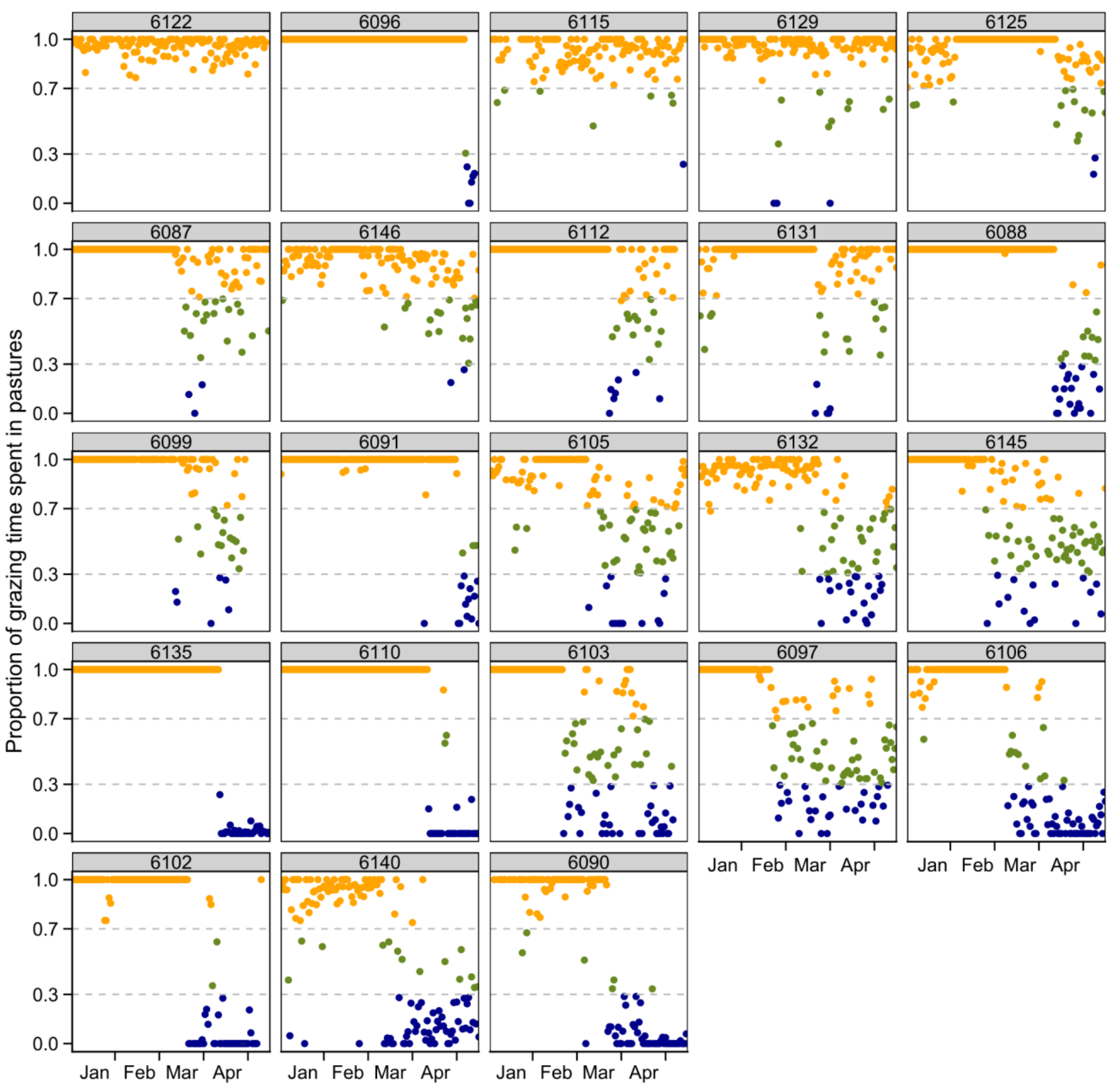

Figure 2 




Figure 3 


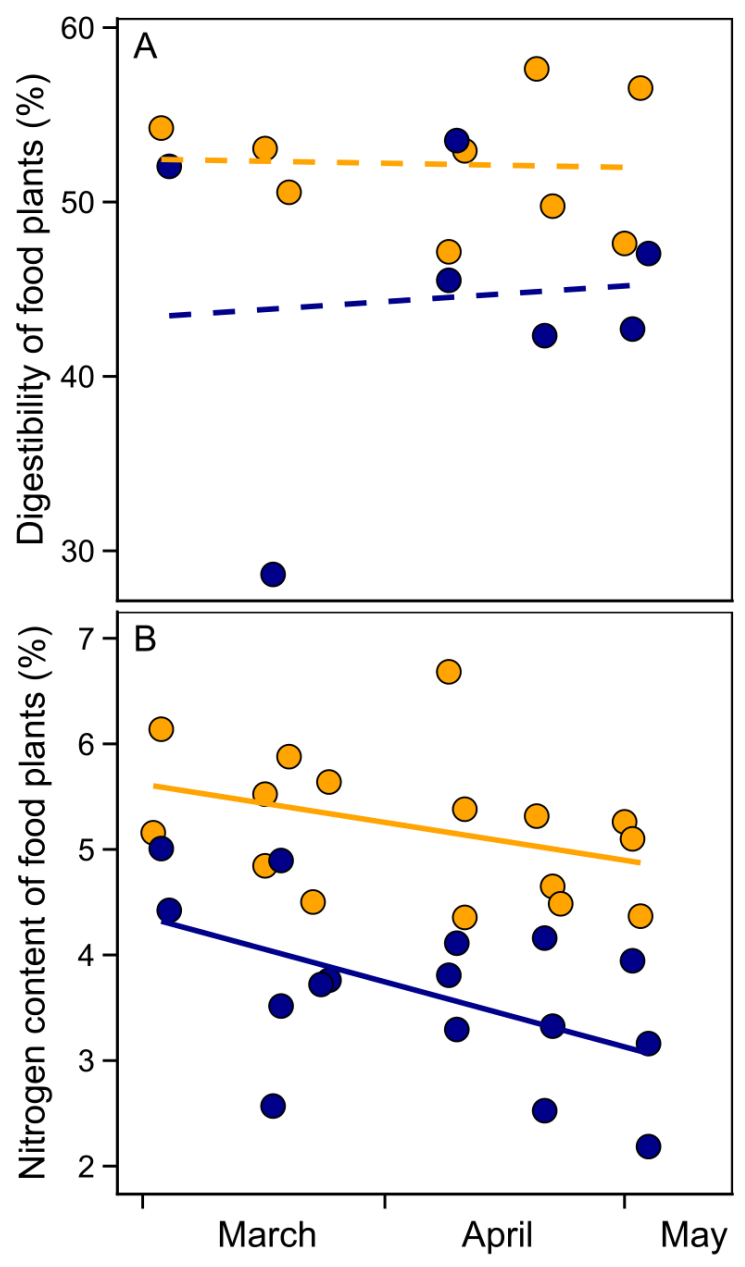

Figure 4 


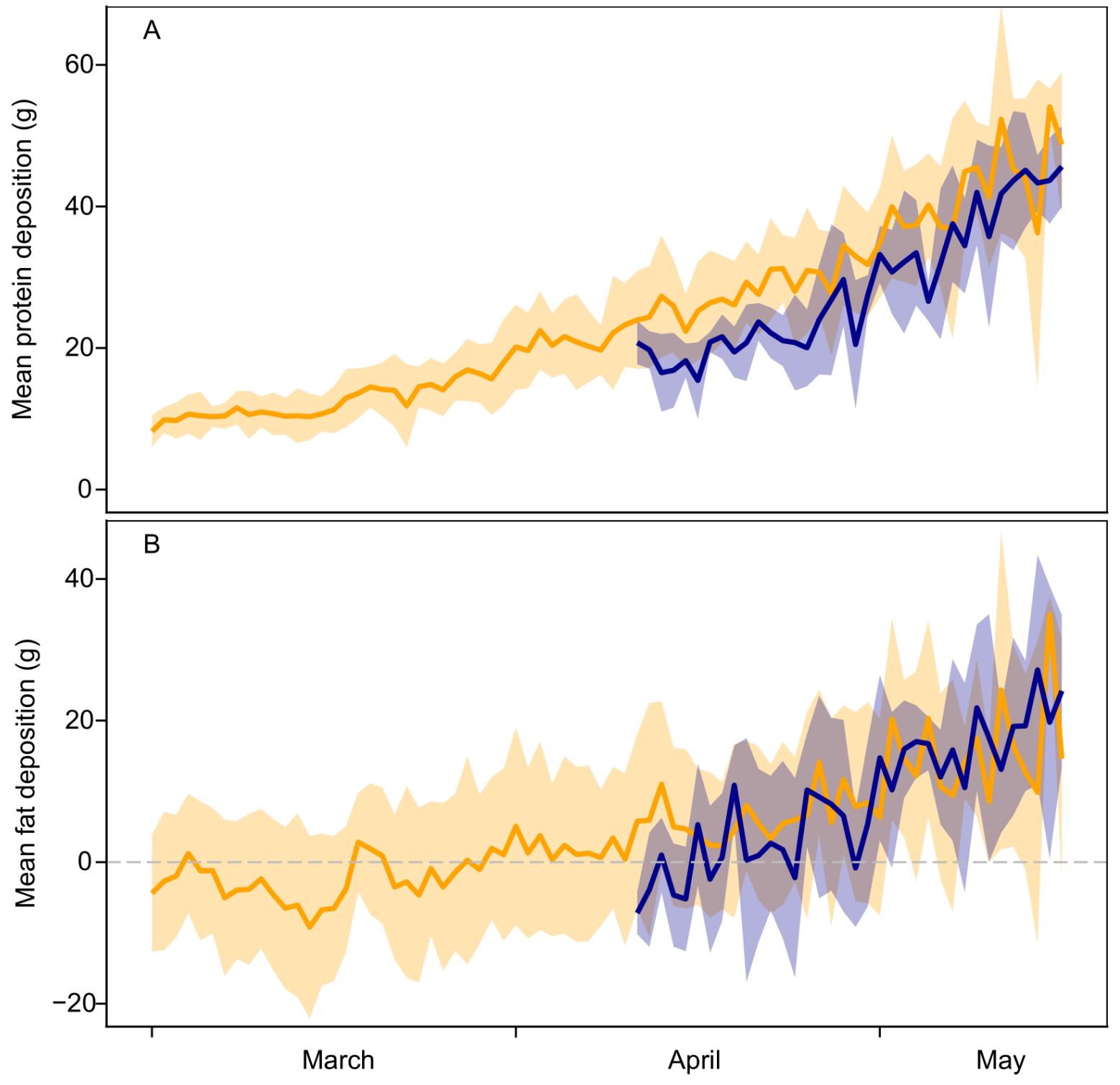

Figure 5 


\section{SUPPLEMENTAL INFORMATION}

\section{Disturbance movements}

We used a dataset with high-frequency GPS-positions (every $5 \mathrm{~min}$ ) to establish a threshold groundspeed above which we expected geese to have made flying movements in 30-min intervals. The dataset was compiled from ten Barnacle Geese caught and equipped with GPS/accelerometer tags in the colony in the Westplaat buitengronden, The Netherlands, in April and May 2016. The GPS/accelerometer tags collected GPS and accelerometer data at 5-min intervals from the moment of catch up to mid-October. We used data between 10 September and 10 October 2016 to exclude periods of breeding, brood rearing and wing moult. We used the accelerometer to distinguish flight behaviour, and recorded the number of GPS-fixes during which flight behaviour was detected for 30min intervals. We then calculated the great circle distance and speed between the 30-min interval locations. We grouped 30-min intervals in intervals during which flight was recorded at least once (by 5-min interval accelerometer data) and where flight was not detected. The ground speed between 30 min intervals with and without flights differed significantly $(t=-9.74, P<0.001)$ but also showed overlap (Figure S1). With a threshold of $0.28 \mathrm{~m} / \mathrm{s}$ (equal to $1 \mathrm{~km} / \mathrm{h}$ ), $42 \%$ of the 30 -min intervals with flights were classified correctly as intervals with flights, while $23 \%$ of the intervals without flights were also classified as to include flights. While our dataset in combination with a threshold method may not be the best way to detect disturbance movements, we argue that it at least can give us a preliminary idea on differences in disturbance movements between habitats.

\section{Food quality}

Dropping mass increased significantly with day of year in pastures (GLM: $0.08 \pm 0.10, t=5.28, n=$ $10, P<0.001)$, but not in salt marshes ( $t=1.86, n=7, P=0.12$, Figure S2A). There was no difference in dropping mass between pastures and salt marshes (GLM habitat: $F_{1,14}, P=0.85$ ). Nitrogen content in droppings decreased significantly with day of year in pastures $(0.20 \pm 0.67, t=$ $3.07, n=10, P=0.02$, Figure S2B), but not in salt marshes $(t=2.22, n=6, P=0.09)$. Nitrogen content in droppings was significantly higher in pastures compared to salt marshes (mean $\pm \mathrm{SD}$, pastures: $5.08 \pm 1.63$, salt marshes: $4.42 \pm 0.58$, GLM habitat: $F_{1,13}, P=0.048$ ). 


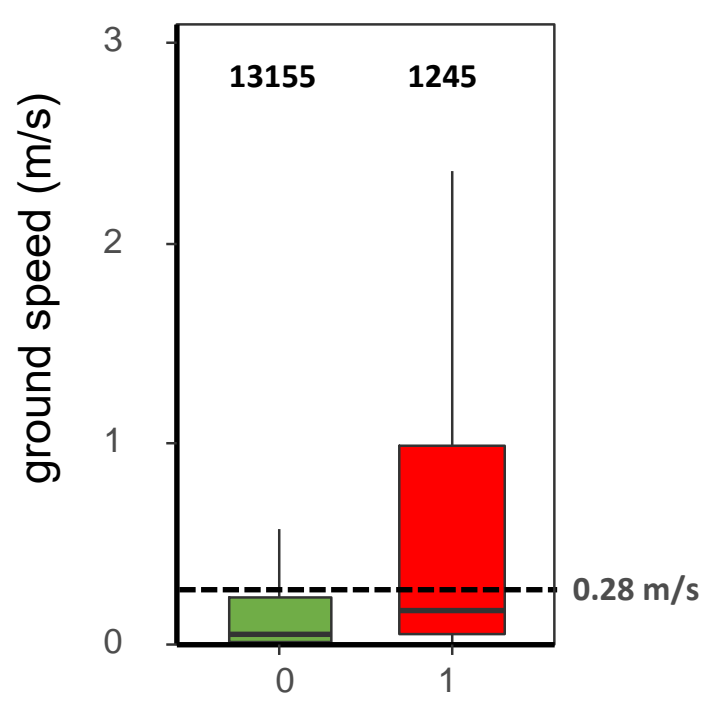

With or without flights

Figure S1. Boxplots showing the groundspeed in $\mathrm{m} / \mathrm{s}$ for 30-min intervals with (1) and without (0) recorded flights (by accelerometer data for 5-min intervals). Numbers show the sample size per group. The horizontal dashed line shows a threshold of $0.28 \mathrm{~m} / \mathrm{s}(1 \mathrm{~km} / \mathrm{h})$. 

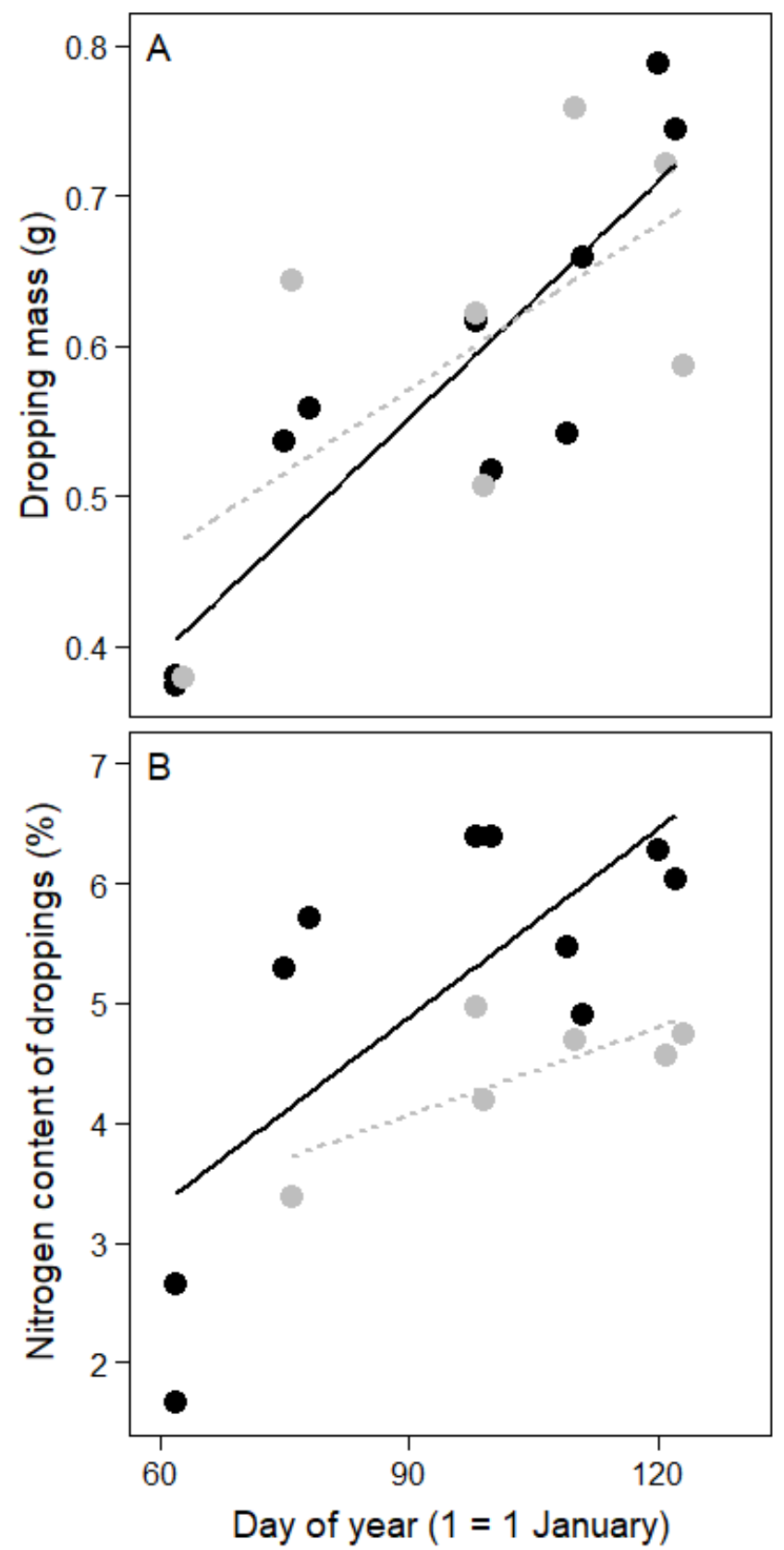

Figure S2. Plots showing (A) dropping mass (g) and (B) nitrogen content of droppings (\%) with day of year in pastures (black) and salt marshes (grey). Lines show linear regressions which are significant, the dashed lines show non-significant linear regressions. 